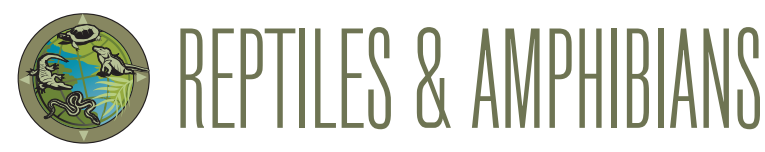

\title{
The Post-tsunami Status of Reticulated Pythons, Malayopython reticulatus (Schneider 1801), in the Nicobar Archipelago, India
}

\author{
Nehru Prabakaran and Chinnasamy Ramesh
}

Wildlife Institute of India, Chandrabani, Dehradun-248001,Uttarakhand, India (ramesh.czoo@gmail.com)

$\mathrm{T}$ he Reticulated Python (Malayopython reticulatus), which is distributed across southern and southeastern Asia, can exceed $7 \mathrm{~m}$ in length and is probably the world's longest snake (Auliya et al. 2002; Lang 2010; Reed and Rodda 2009). In India, the species has a limited distribution, with established populations in the Nicobar Archipelago and sporadic occurrences in eastern India (Tikader 1983; Whitaker and Captain 2004; Mukherjee et al. 2012). Only the Nicobar Archipelago is thought to support viable populations of this species (Sharma 2003; Whitaker and Captain 2004; Vijayakumar and David 2006).

The Nicobar Archipelago, situated in the Bay of Bengal $\left(06^{\circ} 45^{\prime}-9^{\circ} 15^{\prime} \mathrm{N}, 92^{\circ} 42^{\prime}-93^{\circ} 50^{\prime} \mathrm{E}\right)$, consists of 21 islands, of which 12 are inhabited by humans (Fig. 1). The tropical humid climate and high mean annual rainfall of $265 \mathrm{~cm}$ (Kumar et al. 2012) provide suitable conditions for luxuriant tropical rainforests with canopies that often reach heights of $45 \mathrm{~m}$. The total area of the archipelago is $1,841 \mathrm{~km}^{2}$ of which more than $80 \%$ is covered by forest (Porwal et al. 2012). Major vegetation types include coastal littoral forest/lowland forests (Fig. 2), Andaman giant evergreen forests, mangroves, and coconut plantations.

The ongoing existence of Reticulated Pythons in the Nicobar Archipelago is ecologically critical, as these snakes are the only large terrestrial predators in island habitats. However, an extensive field study of reptiles carried out across 15 islands in the archipelago before the 2004 Indian Ocean tsunami recorded only four Reticulated Pythons (Vijayakumar and David 2006).

Since the earliest record of the species from the area by Blyth (1846), many researchers have documented its presence in the archipelago (Biswas and Sanyal 1977, 1980; Baskar and Rao 1992; Das 1999; Vijayakumar and David 2006). Reticulated Pythons are known to occur on 11 (Great Nicobar, Menchal, Katchall, Nancowry, Little Nicobar,
Kamorta, Trinket, Teresa, Bomboka, Tillanchong, and Car Nicobar) of the 21 islands (Vijayakumar and David 2006), but detailed records are available only for the first four islands

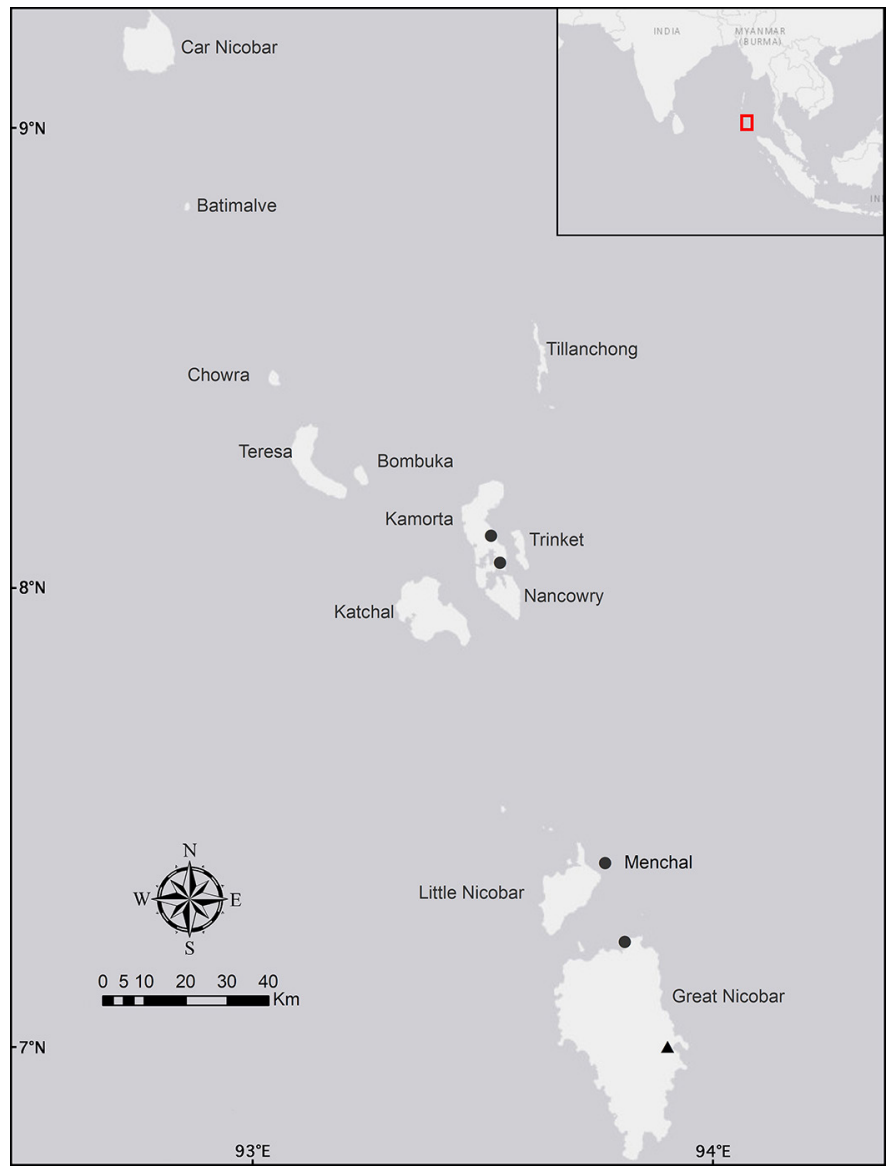

Fig. 1. Locations of encounters with Reticulated Pythons (Malayopython reticulatus) from three islands of the Nicobar Archipelago are marked by dots. Two records from Rajeshkumar et al. (2015) are indicated by the triangle. Records on Katchall and Nancowry islands by Vijayakumar and David (2006) are not marked because no GPS coordinates are available. 


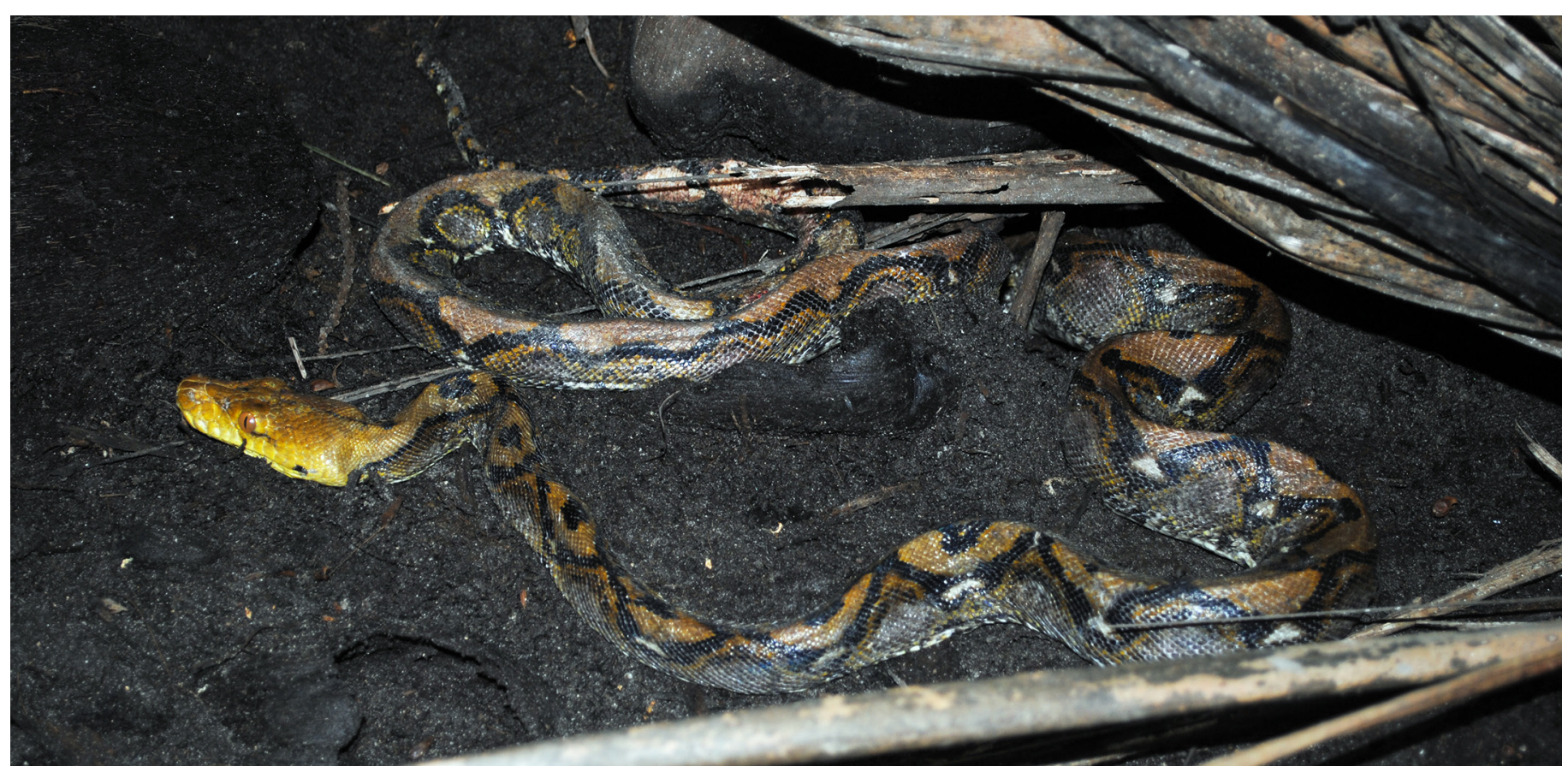

Fig. 2. The only live Reticulated Python (Malayopython reticulatus) encountered during this study was from Menchal Island. Photograph by Nehru Prabakaran.

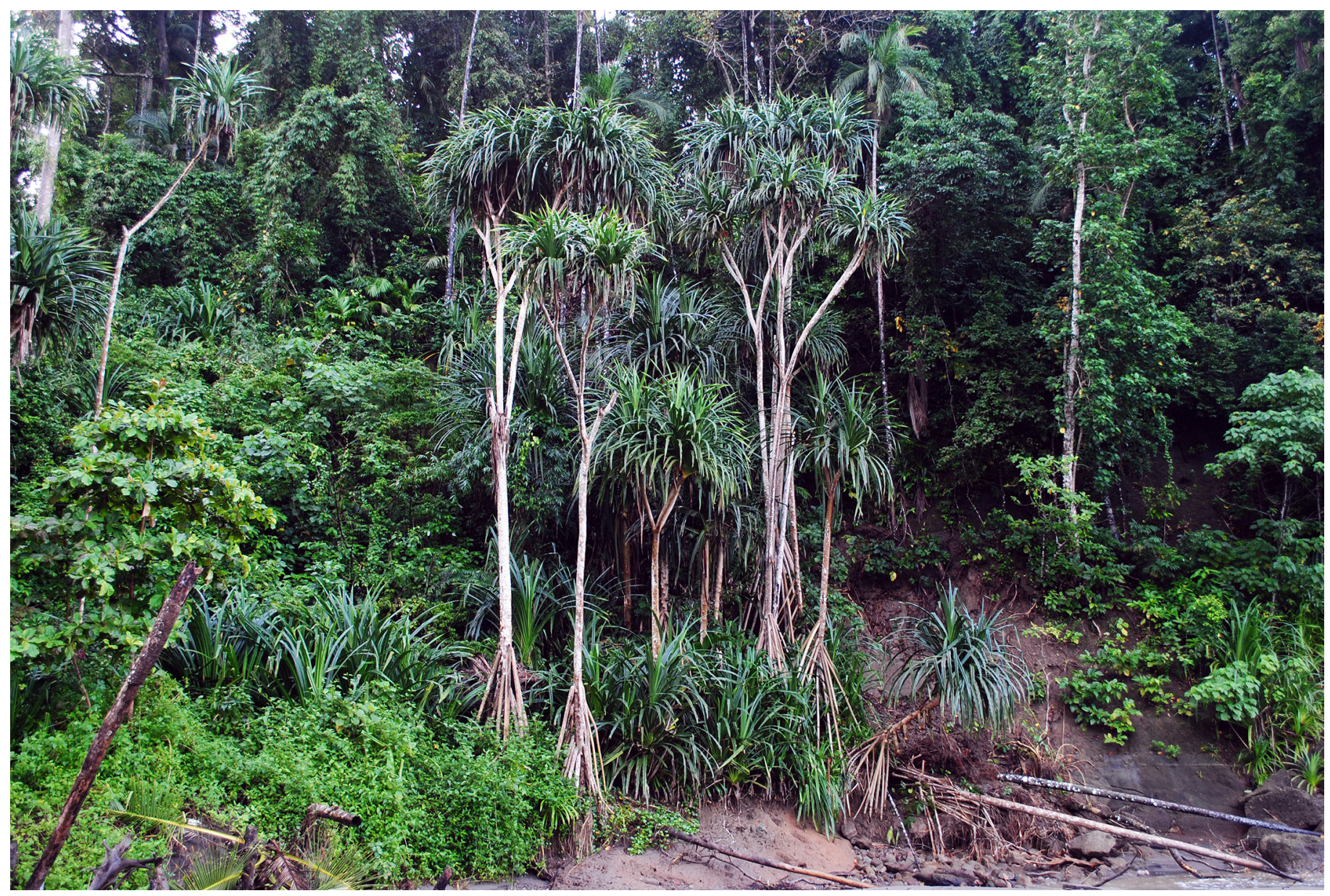

Fig. 3. Reticulated Python (Malayopython reticulatus) habitat in lowland forest on Menchal Island. Photograph by Nehru Prabakaran. 
listed (Biswas and Sanyal 1977, 1980; Vijayakumar and David 2006).

Habitats in which Reticulated Pythons occur include lowland forest, hill slopes, and plantations, but they were most frequently encountered in lowland forests (Vijayakumar and David 2006; Sivakumar 2010). However, the lowland forests of the archipelago were severely damaged by the 2004 Indian Ocean tsunami. Additionally, tsunami-mediated subsidence has permanently altered lowland habitats (Prabakaran and Paramasivam 2018). That not even one Reticulated Python was encountered during an extensive survey in the lowland forests of the archipelago immediately after the tsunami exemplifies the impact of these disturbances on the populations of this species (Sivakumar 2010). Records of the post-tsunami status of Reticulated Pythons in the Nicobar Archipelago are limited to initial observations by Sivakumar (2010) and a report of the rescue of two pythons from Great Nicobar Island (Rajeshkumar et al. 2015). We implemented the present study to provide insights on the post-tsunami status, distribution, and conservation needs of the species.

In addition to a review of the literature, we conducted extensive fieldwork in the lowland forests of the Nicobar Archipelago between October 2009 and August 2011 and again between April 2019 and January 2020. These were supplemented by exploratory surveys outside the sampling periods and opportunistic observations. We spent a total of 214 field days and carried out repeated surveys of 1150.1 ha vegetation plots and 25 belt transects of various lengths $(100-500 \mathrm{~m} \times 5 \mathrm{~m})$ on 18 islands. Three islands (Pigeon, Batimalve, and the Isle of Man) could not be surveyed. In addition to extensive vegetation sampling, we recorded the occurrence of Reticulated Pythons.
In addition to two Reticulated Pythons recorded from Great Nicobar Island by Rajeshkumar et al. (2015), we encountered four pythons during our surveys, one of which was alive (Fig. 3) and three of which were dead (Table 1). Sizes of snakes $(1.35-2.85 \mathrm{~m})$ indicated that they were less than four years of age. These observations and interviews with local residents suggest that the species became rare after the tsunami. Sivakumar (2000) stated that young pythons were frequently encountered in lowland forest. However, a posttsunami survey by Sivakumar (2010) recorded no pythons. That study and our observations suggest that the tsunami plus ongoing human-related threats have decimated the populations of Reticulated Pythons in the Nicobar Archipelago.

Human-mediated threats to pythons involve exploitation, persecution, and alterations and destruction of habitat. The forest-dwelling Shompens, one of two aboriginal communities in the islands who live only on Great Nicobar, eat pythons (Vijayakumar and David 2006). Our interviews with local residents also revealed that some settlers from mainland India residing in the central group of islands also occasionally consume these snakes. The Nicobarese, the other aboriginal entity and the most populous community in the archipelago, apparently do not eat pythons, but usually kill them on sight (Fig. 4) as they are culturally regarded as an element of destruction (Chandi 2006). The Nicobarese name for this snake, yammai kamai (= "eater of our chicken"), epitomizes the negative perception of pythons.

Populations of Reticulated Pythons across the species' range are under immense pressure largely attributable to harvesting skins for the leather industry - it is the most widely traded snake species in the world - and retaliatory killing (Lang 2010; Murray-Dickson et al. 2017). Although harvest-

Table 1. Reticulated Pythons (Malayopython reticulatus) encountered during the study period in the Nicobar Archipelago, India. Note that Vijayakumar and David (2006) observed individuals on Great Nicobar, Menchal, Nancowry, and Katchall, but neither coordinates nor other details are available.

\begin{tabular}{lccll} 
Island & Date & Coordinates & $\begin{array}{c}\text { Length } \\
(\mathbf{m})\end{array}$ & Remarks \\
\hline Great Nicobar & 22 Dec 2009 & $7.229472^{\circ} \mathrm{N}, 93.80911^{\circ} \mathrm{E}$ & 2.07 & Killed near human habitation in lowland forest \\
\hline Menchal & 15 May 2011 & $7.401028^{\circ} \mathrm{N}, 93.76633^{\circ} \mathrm{E}$ & 2.40 & Resting under a Pandanus tree in lowland forest \\
\hline Kamorta & 03 Dec 2010 & $8.113244^{\circ} \mathrm{N}, 93.51840^{\circ} \mathrm{E}$ & 2.11 & Roadkill near human habitation in island interior \\
\hline Kamorta & 21 Jan 2020 & $8.054592^{\circ} \mathrm{N}, 93.53787^{\circ} \mathrm{E}$ & 2.85 & $\begin{array}{l}\text { Killed after preying on domestic chickens near human } \\
\text { habitation near forest }\end{array}$ \\
\hline
\end{tabular}

Records of Reticulated Pythons from Govind Nagar on Great Nicobar by Rajeshkumar et al. (2015)

\begin{tabular}{lcccl}
\hline Great Nicobar & $25 \mathrm{Mar} 2013$ & $7^{7.001233^{\circ} \mathrm{N}, 93.90213^{\circ} \mathrm{E}}$ & 2.06 & $\begin{array}{l}\text { Found near human settlement preying on domestic } \\
\text { chickens. Locals tried to kill the snake but it was rescued }\end{array}$ \\
\hline Great Nicobar & $31 \mathrm{Mar} 2013$ & $7.001233^{\circ} \mathrm{N}, 93.90213^{\circ} \mathrm{E}$ & 1.35 & Captured by locals and released \\
\hline
\end{tabular}



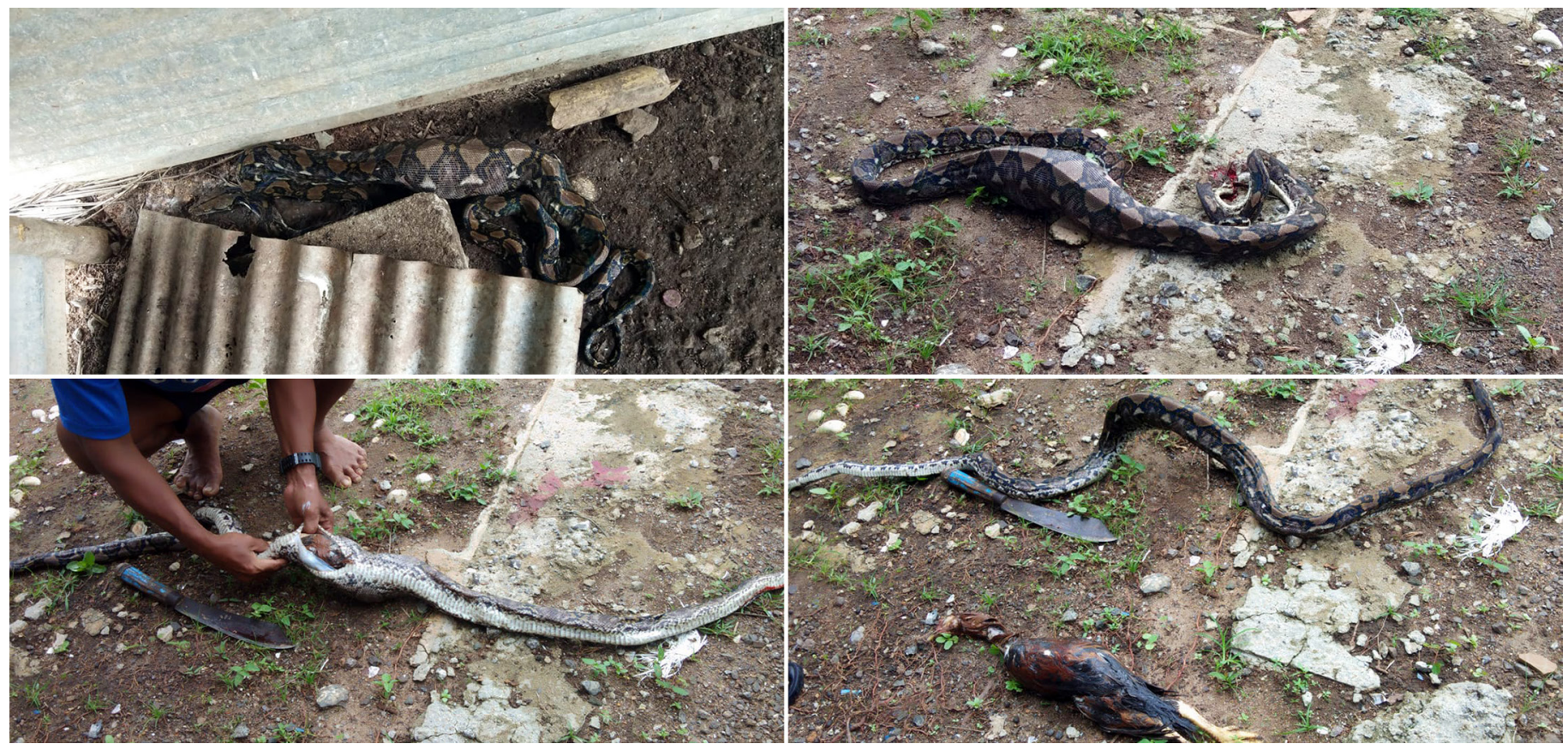

Fig. 4. Reticulated Pythons (Malayopython reticulatus) are culturally regarded as elements of destruction and the Nicobarese often kill snakes that can prey on domestic chickens and pigs. This python was killed after eating a domestic chicken on Kamorta Island. Photograph by Saffeque.

ing of wild populations for the leather industry is prevalent in the Indonesian Archipelago (Shine and Harlow 1999), that trade has not yet reached the Nicobar Islands. However, Vijayakumar and David (2006) indicated that habitat destruction and persecution played major roles in pre-tsunami population declines of pythons in the archipelago — and these continue today. The recent thrust for economic development by promoting tourism and other activities (Giles 2018) on top of the ongoing clearing of forests for coconut plantations and human settlements and the unsustainable harvesting of natural resources associated with a growing human population (Saini 2013) might render the long-term survival of Reticulated Pythons in the Nicobar Archipelago untenable.

Further complicating matters is that no specimens from the Nicobar Archipelago were included in the phylogenetic study by Murray-Dickson et al. (2017), who emphasized that any conservation efforts must focus on genetically distinct populations. The survival of Reticulated Pythons in the archipelago will depend on detailed long-term studies focusing on the species' ecology and population status. However, these must be accompanied by efforts to create an awareness in local human communities about the ecological significance of the species and by establishing a monetary compensation program for the loss of poultry and pigs to snakes in order to offset the negative perceptions of pythons.

\section{Acknowledgments}

We are grateful to the INSPIRE program of the Department of Science and Technology, India, for funding the study (grant no. DST/INSPIRE/04/2018/001071). We thank the forest department of the Andaman and Nicobar Islands for field permits and facilitating the study with logistical support. We are thankful to several people from the Nicobarese community for sharing their knowledge and helping us during fieldwork. We are grateful to Mr. Saffeque for sharing photographs used in Fig. 4. We are indebted to the Dean and the Director of the Wildlife Institute of India for their kind support.

\section{Literature Cited}

Auliya, M., P. Mausfeld, A. Schmitz, and W. Böhme. 2002. Review of the reticulated python (Python reticulatus Schneider, 1801) with the description of new subspecies from Indonesia. Naturwissenschaften 89: 201-213. DOI 10.1007/ s00114-002-0320-4.

Baskar, S. and G.C. Rao. 1992. Present status of some endangered animals in Nicobar Islands. Journal of Andaman Science Association 8: 181-186.

Biswas, S. and D.P. Sanyal. 1977. Notes on the Reptilia collection from the Great Nicobar Island during the Great Nicobar Expedition in 1966. Records of the Zoological Survey of India 72: 107-124.

Biswas, S. and D.P. Sanyal. 1980. A report on the Reptilia fauna of Andaman and Nicobar Islands in the collection of Zoological Survey of India. Records of the Zoological Survey of India 71: 255-292.

Blyth, E. 1846. Notes on the fauna of the Nicobar Islands.-Reptilia. Journal of the Asiatic Society of Bengal 15: 367-379.

Chandi, M. 2006. The use and knowledge of herpetofauna on Little Nicobar Island, India. Conservation and Society 4: 155-165.

Das, I. 1999. Biogeography of the amphibians and reptiles of the Andaman and Nicobar Islands, pp. 43-77. In: H. Ota (ed.), Tropical Island Herpetofauna. Origin, Current Diversity, and Conservation. Developments in Animal and Veterinary Sciences, 29. Elsevier Science B.V., Amsterdam, The Netherlands.

Giles, D. 2018. The beginning of the end of Andaman \& Nicobar's particularly vulnerable tribal groups. DownToEarth, 3 October 2018. https://www.downtoearth.org.in/blog/environment/the-beginning-of-the-end-of-andamannicobar-s-particularly-vulnerable-tribal-groups-61778.

Kumar, N., B.P. Yadav, A. Tyagi, and A.K. Jaswal. 2012. Trend and spatial distribution of rainfall \& rainy days over Andaman \& Nicobar Islands. Natural Hazards 63: 575-587. https://doi.org/10.1007/s11069-012-0173-x. 
Lang, R. 2010. The reticulated python (Broghammerus reticulatus) and man (Homo sapiens) eat each other: Animals, enjoy your meal! Litteratura Serpentium 30: 254-269.

Mukherjee, S., V. Santra, and G. Aditya. 2012. Reticulated Python, Python reticulatus (Schneider, 1801) in Hooghly, West Bengal, India. Proceedings of the Zoological Society 65 (2): 114-117. DOI 10.1007/s12595-012-0032-5.

Murray-Dickson, G., M. Ghazali, R. Ogden, R. Brown, and M. Auliya. 2017. Phylogeography of the reticulated python (Malayopython reticulatus ssp.): Conservation implications for the world's most traded snake species. PloS One 12: e0182049. https://doi.org/10.1371/journal.pone.0182049.

Porwal, M.C., H. Padalia, and P.S. Roy. 2012. Impacts of tsunami on the forest and biodiversity richness in Nicobar Islands (Andaman and Nicobar Islands), India. Biodiversity and Conservation 21: 1267-2128. https://doi.org/10.1007/ s10531-011-0214-x.

Prabakaran, N. and B. Paramasivam. 2014. Recovery rate of vegetation in the tsunami impacted littoral forest of Nicobar Islands, India. Forest Ecology and Management 313: 243-253. DOI: 10.1016/j.foreco.2013.11.023.

Rajeshkumar, S., C. Raghunathan, and K. Chandra . 2015. Reticulated python Malayopython reticulatus (Schneider 1801): Rescue, recovery and recent sightings from Great Nicobar Island - a conservation approach. Ecoprint 22: 50-55. https://doi.org/10.3126/eco.v22i0.15470.

Reed, R.N. and G.H. Rodda. 2009. Giant Constrictors: Biological and Management Profiles and an Establishment Risk Assessment for Nine Large Species of Pythons, Anacondas, and the Boa Constrictor. Open-File Report 2009-1202, U.S. Geological Survey, Reston, Virginia, USA.
Saini, A. 2013. Post-tsunami Socio-cultural Changes among the Nicobarese: An Ethnography of the Nicobarese of the Southern Nicobar Islands. TISS Working Paper 1. Tata Institute of Social Sciences, Mumbai, India.

Sharma, R.C. 2003. Handbook. Indian Snakes. Zoological Survey of India, Kolkata, India.

Shine, R. and P.S. Harlow. 1999. Reticulated pythons in Sumatra: biology, harvesting and sustainability. Biological Conservation 87: 349-357. https://doi. org/10.1016/S0006-3207(98)00068-8.

Sivakumar, K. 2000. A Study on the Breeding Biology of the Nicobar Megapode Megapodius nicobariensis. Unpublished Ph.D. Dissertation, Bharathiyar University, Coimbatore, India.

Sivakumar, K. 2010. Impact of tsunami on certain rare and threatened species of Nicobar group of Islands with special reference to the Nicobar Megapode Megapodius nicobariensis, pp. 435-441. In: Ramakrishna, C. Raghunathan, and C. Sivaperuman (eds.), Recent Trends in Biodiversity of Andaman and Nicobar Islands. Zoological Survey of India, Kolkata, India.

Tikader, B.K. 1983. Threatened Animals of India. Zoological Survey of India, Kolkata, India.

Vijayakumar, S.P. and P. David. 2006. Taxonomy, natural history, and distribution of the snakes of Nicobar Islands (India), based on new materials and with an emphasis on endemic species. Russian Journal of Herpetology 13: 11-40.

Whitaker, R. and A. Captain. 2004. Snakes of India. The Field Guide. Draco Books, Chennai, India. 